\title{
SOLAR DRYING OF JACK FRUIT ALMONDS ${ }^{1}$
}

\section{ALEXANDRE J. DE M. QUEIROZ ${ }^{2}$, HERMEVAL J. DANTAS ${ }^{3}$, ROSSANA M. F. DE FIGUEIRÊDO ${ }^{2}$, KARLA DOS S. MELO ${ }^{4}$}

\begin{abstract}
Dryers heated by solar energy have been constructed and used in drying whole and half jack fruit almonds. The samples were dried during the day in direct sun and in the conventional solar dryer prepared for this purpose. Another piece of equipment was built for reception and accumulation of sun energy in a body of water, which was used as a heat source for night drying. The drying with the sun energy was compared with artificial drying. The jack fruit almonds were dried whole, half, with pellicle and without it. The storage of solar energy in water was technically viable for use in night drying. The drying by combining solar dryers in the day and night periods were completed in approximately 35 hours, and were equivalent to artificial drying between $40^{\circ} \mathrm{C}$ and $70^{\circ} \mathrm{C}$. Almond cut in half and the pellicle removed reduced the drying time.
\end{abstract}

KEYWORDS: Artocarpus heterophyllus, solar dryer, agricultural residues.

\section{SECAGEM SOLAR DE AMÊNDOAS DE JACA}

RESUMO: Secadores com aquecimento por energia solar foram construídos e utilizados em secagens de amêndoas de jaca inteiras e em metades. As secagens no período diurno foram realizadas por exposição direta ao sol e em secador solar convencional, elaborado para este fim. Construiu-se também um equipamento para captação e acumulação de energia solar em uma massa de água, a qual foi utilizada como fonte de calor para realização de secagens no período noturno. As secagens com o uso de energia solar foram comparadas com secagens artificiais. As amêndoas de jaca foram secadas inteiras, em metades, com e sem película. O armazenamento da energia solar em corpo de água mostrou-se viável do ponto de vista técnico para utilização em secagens noturnas. As secagens combinando secadores por energia solar nos períodos diurno e noturno foram concluídas em tempos aproximados de 35 horas e equivaleram a secagens artificiais entre $40^{\circ} \mathrm{C}$ e $70{ }^{\circ} \mathrm{C} . \mathrm{O}$ corte das amêndoas e a retirada das películas reduziram o tempo de secagem.

PALAVRAS-CHAVE: Artocarpus heterophyllus, secador solar, resíduos agrícolas.

\section{INTRODUCTION}

Materials classified as agricultural residues are often valuable materials from the nutritional point of view, and they can be used to increase profitability to the main product. In addition, the disposal of these products has negative environmental consequences, proportional to the size of exploration.

Jack fruit seeds resulting from the use of pulp in the manufacture of candy, jellies and others constitute agro-industrial residues rich in nutrients, with good sensory characteristics, resembling in flavor the jatropha. They may be commercialized in similar presentations to almonds or nuts, whether roasted or cooked, fresh or containing sugar or salt. They are of a similar size of the Brazil nut, which can be eaten whole or utilized in the form of flour, incorporated in bakery products.

\footnotetext{
${ }^{1}$ Extraído da dissertação de mestrado defendida pelo segundo autor. Programa de Pós-Graduação em Engenharia Agrícola da UFCG.

${ }^{2}$ Dr. Eng. Alimentos, Prof. Associado II, Unidade Acadêmica de Engenharia Agrícola, UFCG, Campina Grande - PB, Av. Aprígio Veloso, 882, Bairro Universitário, Fone: (0XX83) 3310-1547, alex@ deag.ufcg.edu.br, rossana@deag.ufcg.edu.br.

${ }_{3}^{3}$ M.Sc. Eng. Agrícola, Unidade Acadêmica de Engenharia Agrícola, UFCG, Campina Grande - PB, hermevalj@gmail.com.

${ }^{4}$ M.Sc. Eng. Agrícola, Prof ${ }^{\text {. }}$ Assistente I, Unidade Acadêmica de Tecnologia do Desenvolvimento, UFCG, Sumé - PB, karlamelo@ufcg.edu.br.

Recebido pelo Conselho Editorial em: 24-2-2011
}

Aprovado pelo Conselho Editorial em: 15-8-2011 
The jack fruit seed constitute an almond with good protein, carbohydrates, phosphorus, calcium, fiber and vitamins A and thiamin (GIRALDO-ZUÑIGA et al., 2004). TULYATHAN et al. (2002) determined the amount of protein and carbohydrates on a dry basis of 0.11 and 0.816 , respectively.

The conservation of the jack fruit seed, which is called in this study as jack fruit almond with a view to its use for food, is made possible after drying, since its water content after the removal of the pulp is about $50 \%$.

The use of solar drying or natural drying is ideal for products whose chance of entering the market depends on a low cost of processing, such as jack fruit almonds; thus, a product treated as a waste, despite the nutritional value, would be benefited from the reduced costs by drying, allowing the commercialization on a competitive price.

The solar or natural drying is replaced, whenever possible, by artificial drying, which allows greater process control and uninterrupted operation. The rising price of fossil fuels and the overall increase of energy consumption, however, renew the prospects for the use of solar energy for drying agricultural products, which is distinguished by the low operating costs, the use of renewable energy source, and by the environmental neutrality, advantages which tend to have increasing importance.

One disadvantage of its use is the termination of drying at night. In studies to overcome this drawback, it should be consider the accumulation of solar energy during the day in order to use it to further drying at night, which is usually done with the fabrication of dryers with materials with high heat capacity, such as bricks and stones (MARTINS et al., 2002), which retain heat, but only in the early hours of the night. Heat storage with greater capacity should be studied in order to increase the effectiveness of drying with solar energy.

The use of a body of water to accumulate solar energy has the advantage of being performed in a relatively small volume, and to carry out its heat through simple solar collectors, built on the principle of direct heating of water in a pipe inserted in a box with glass top. In this type of arrangement, a greenhouse effect is created which can raise the water temperature to values of $80{ }^{\circ} \mathrm{C}$ or more, depending on the construction details, such as thermal insulation to the external environment.

This study was carried out in order to build a conventional solar dryer, a heat accumulator dryer based on solar energy for night drying, and to use both to dry jack fruit almonds and compare the dryings on these conditions with artificial drying.

\section{MATERIAL AND METHODS}

This study was conducted at the Laboratory of Storage and Processing of Agricultural Products of the Academic Unit of Agricultural Engineering, of the Center for Technology and Natural Resources of the Federal University of Campina Grande, State of Paraíba, Brazil, from July 2006 to February 2007.

Jack fruit seeds (Artocarpus heterophyllus Lam.), of "soft" variety were used. Aiming food production, and because they were used in treatments at temperatures above $50{ }^{\circ} \mathrm{C}$, which prevents germination, seeds were referred to as "nuts". Moisture of the samples was determined by the oven method at $105^{\circ} \mathrm{C}$, during $24 \mathrm{~h}$.

In order to evaluate the drying in the most likely commercial presentations, the almonds were studied in whole and halves. They were also studied with the surface pellicle surrounding it and without it, in a total of four samples: Whole with Pellicle (WP), Whole without Pellicle (WWP); Half with Pellicle (HP), and Half without Pellicle (HWP).

For the drying of the almonds, it was used two methods of solar drying, both with more than 24 hours: in the first, the samples were dried by direct exposure to the sun at daytime, combined 
with the dryer Heat Accumulator for Night Drying (HAND dryer), at night; and, in the second method, with the conventional solar dryer in the daytime combined with the HAND dryer at night. It was verified the efficiency of the HAND dryer, through control samples that were separate from the lot that went to the HAND dryer at night, placed in the shelter under ambient conditions, where they remained overnight. In the next-morning, they returned to drying by direct exposure to sun or conventional solar dryer.

The conventional solar dryer (Figure 1) was prepared in galvanized metal sheet, coated internally with expanded polystyrene (Styrofoam), painted in black, with the coverage of a flat glass of $3.0 \mathrm{~mm}$ thick. The dryer, with a square format, measured $710 \mathrm{~mm}$ edge and $120 \mathrm{~mm}$ deep, with $90 \mathrm{~mm}$ of free space, where the samples were placed.

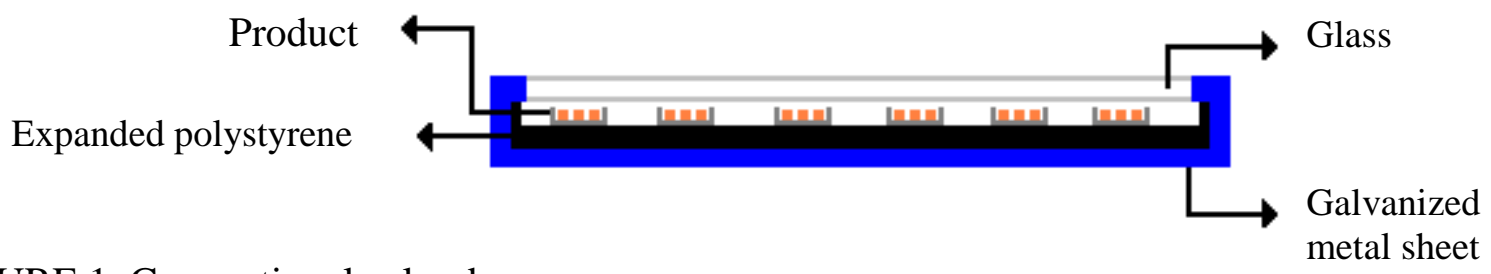

FIGURE 1. Conventional solar dryer.

metal sheet

For the overnight drying, using solar energy stored, the HAND dryer (Figure 2) was built with heating water system through solar collectors. The heated water during the day was stored in a thermally insulated tank and used at night as a source of heat for the drying chamber, where it circulated beneath the trays containing the samples, going through a heat exchanger consisting of a copper tube coil.

The solar collectors were of the flat plate type, with a system of internal copper tubes for water circulation. Each collector was made of aluminum housing, thermal insulation of glass wool, heat absorber plate and transparent glass cover of $3.0 \mathrm{~mm}$ thick. The frame was rectangular $(1.02 \mathrm{x}$ 1.72 , and $0.12 \mathrm{~m}$ deep), the lower face and the sides were covered with thermal insulation where the absorber plate made of aluminum sheet was placed on. The closing of the frame on the upper face was made of a glass cover, using a flexible sealant as an adhesive. The longitudinal axes of the collectors were positioned North and inclined in the same direction of $7^{\circ}$, in order to compensate the local latitude (approximately $7^{\circ}$ South), this slope favors the warming in the months of great use of the equipment, around the summer solstice in the Southern Hemisphere.

To store the heated water in the collectors, it was used a thermal tank made of expanded polystyrene box, with a capacity of $150 \mathrm{~L}$, covered with plastic film to maintain impermeability.

The drying chamber was made of zinc sheet, with a square cross section, measuring $0.26 \mathrm{~m}$ inside and $1.5 \mathrm{~m}$ long; the upper part of the chamber is shaped like a truncated cone, with the aim of reducing the exhaust vent of drying air, avoiding the cooling inside the chamber by the air outside; the interior was covered with thermal insulation made of expanded polystyrene sheets of $30 \mathrm{~mm}$ thick; the interior was fitted with a downward spiral coil, built in copper pipes of nominal diameter of approximately $0.019 \mathrm{~m}$ (3/4 inch), where the heated water circulated and provided heat for the drying; the samples were placed in stainless steel tray, made of perforated screen on aluminum profile; the circulation of air in the chamber was given by natural convection.

The components of the HAND dryer with the items described (collectors, thermal storage tank and the drying chamber) were mounted at different heights, forming two independent circuits of water circulation. The three collectors were connected in parallel, placed in the up position between the first and third. It is considered as the first collector the one placed at a lower relative position, whose input is connected to the lower outlet of cold water of the thermal storage tank, while the third collector is considered the one placed in the highest position among the three, connected to the hot water inlet of the storage tank, forming the first circuit, between the collector and the tank. A similar procedure was applied to the drying chamber, where the pieces, lower 
output and higher input of the thermal storage tank, were connected to the chamber, forming the second circuit. During the day, the collectors heated the water of the thermal storage tank using sunlight; by the effect of thermal siphon, hot water of the collectors followed by ascension to the storage tank, and the cold water of the lower storage tank circulated toward the collectors, covering the first circuit; in the late afternoon, the movement between the collectors and the storage tank was interrupted by registers; for overnight drying the registers of the second circuit were opened, allowing the movement of water between the storage tank and the drying chamber, promoted by thermal siphon, situation where the water ran through the copper coil circuit, internal to the drying chamber, heating the air and promoting the drying of the samples. All lines of the circuits of hot water pipes exposed to the environment were thermally insulated in polyurethane foam.

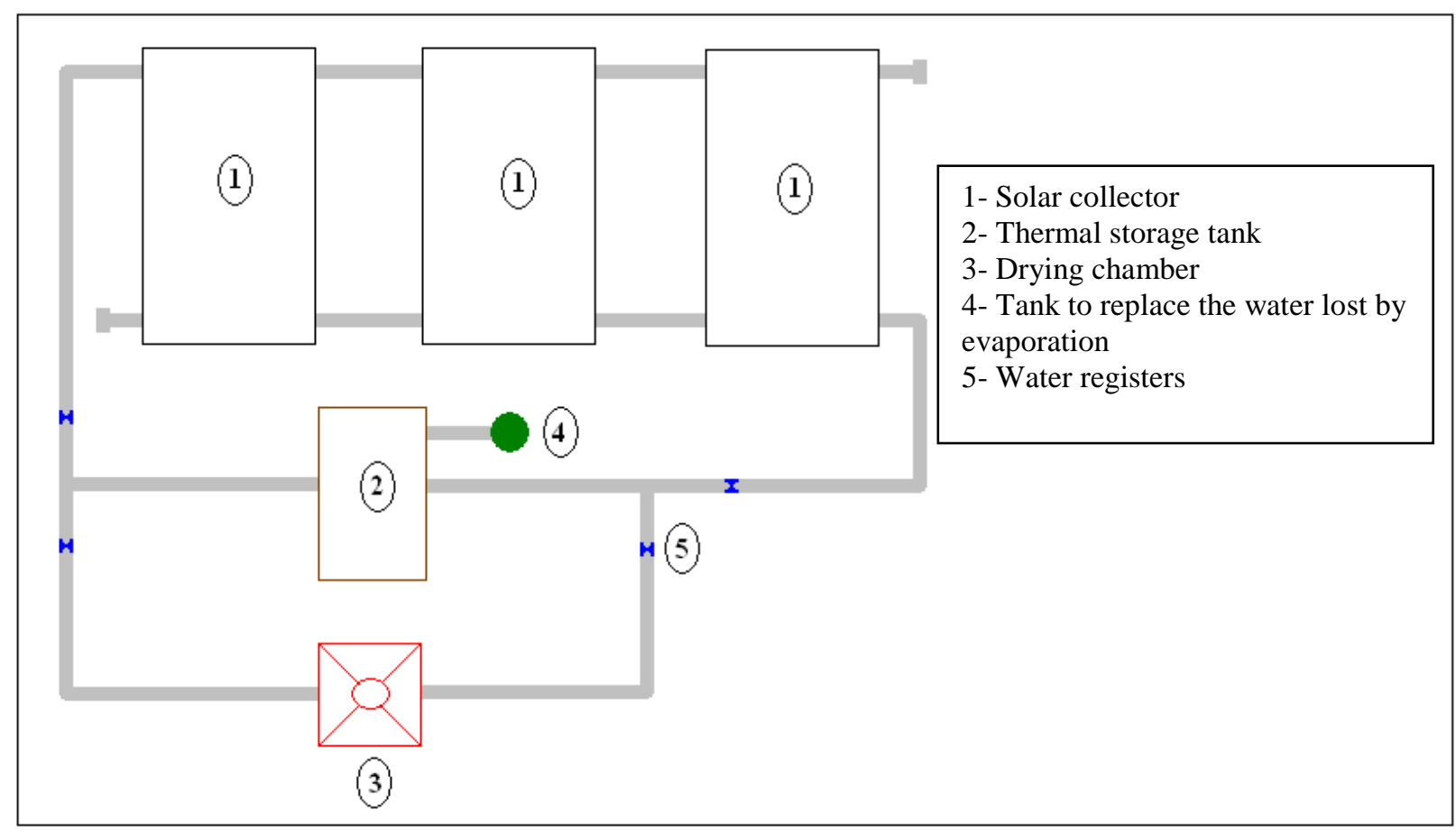

FIGURE 2. Complete system of the HAND dryer.

The drying using direct exposure to the sun and solar dryer combined with the HAND dryer were initiated between 8:30 and 9:00 am, with 12 trays, each containing about $35 \mathrm{~g}$ of almonds. The trays were placed inside the daytime dryer (conventional solar dryer) or exposed to direct sunlight (direct exposure drying), proceeding the weights every 2 hours; at $6 \mathrm{pm}$, half the trays went to the HAND dryer and the other half was placed in a shelter (control), followed by weighing the 12 trays every 4 hours; at $6 \mathrm{am}$, all samples returned to their respective locations (conventional solar dryer or direct exposure to sunlight) and drying continued, with the weights being held thereafter every 4 hours; at $6 \mathrm{pm}$ the samples returned to the HAND dryer or shelter and the procedure of the last night was repeated.

The artificial drying of the samples were performed in thin layer, using an oven with forced air circulation at temperatures of $40{ }^{\circ} \mathrm{C}, 50{ }^{\circ} \mathrm{C}, 60{ }^{\circ} \mathrm{C}$ and $70^{\circ} \mathrm{C}$. The drying was performed with material placed directly on the trays, and the process conducted until the samples reached the equilibrium moisture content.

To adjust the kinetics data for drying of jack fruit almonds, it was used the logarithmic model (Equation 1) applied by the computer program Statistica 5.0.

$$
\mathrm{RX}=\mathrm{A} \exp (-\mathrm{Kt})+\mathrm{C}
$$


In which,

$\mathrm{RX}$ - ratio of water (dimensionless);

$\mathrm{A}, \mathrm{K}$ e C - constants of the model, and

$\mathrm{t}$ - time of drying $(\mathrm{h})$.

\section{RESULTS AND DISCUSSION}

\section{Solar drying in direct sunlight}

Figure 3 shows the experimental points of drying almonds WP, WWP, HWP and HP, with direct sunlight combined with HAND dryer and control (C), adjusted linearly by stretches, consisting of the first overnight drying (N1), in first twelve hours; daylight drying (D1), between 12 and 24 hours; and second overnight drying (N2), from 24 hours. It can be noticed that, in the first 12 hours and after 24 hours, in both periods of overnight drying, the drying in the HAND dryer showed the highest angular coefficients (in absolute value), indicating faster drying and, therefore, better performance compared to control.
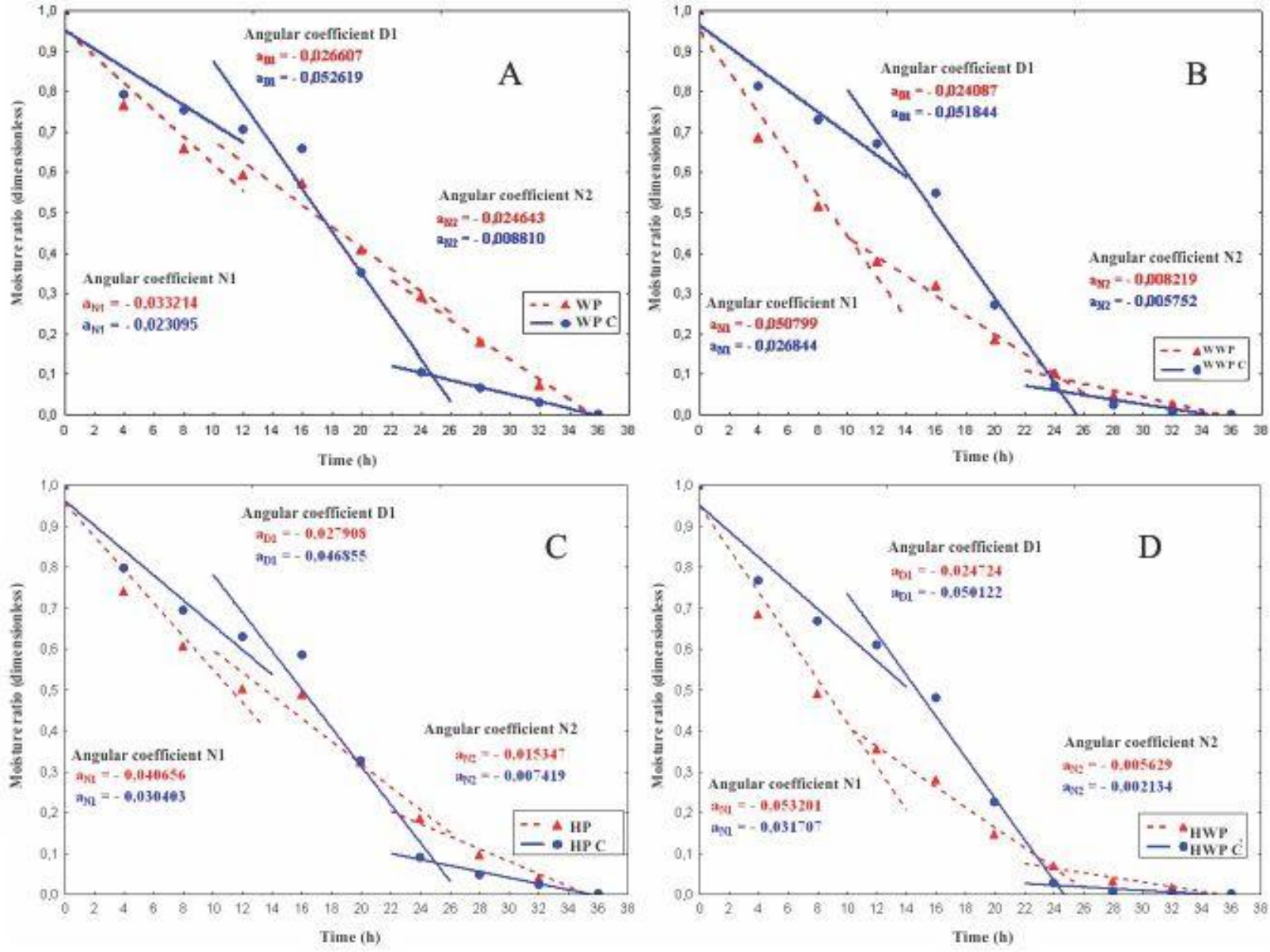

FIGURE 3. Drying curves of almonds WP (A), WWP (B), HP (C) and HWP (D) exposed to the sun, combined with HAND dryer.

The removal of the pellicle and the almonds cut in half directly influenced drying, with the decrease of the moisture ratio in similar times. In the period from 24 to 12 hours, drying stage during the daytime, it is observed that the curves for the samples used as control had a higher angular coefficient (absolute), indicating faster drying; after the 24 hours drying, all samples continued losing water inside the HAND dryer, while the control continued to lose water, but with less intensity. The initial moisture changed from $52 \%$ to $48 \%$ in samples WP, WWP, HWP and HP, and the HAND dryer provided greater loss of water in WP and HP almonds, totaling $2 \%$ and $10 \%$, 
respectively, compared to control. With WWP and HWP almonds the loss was of $8 \%$ compared to control; HWP almonds resulted in better results in drying with the HAND dryer, by reducing the initial moisture content from 50\% to 15\%. AHRENS \& LOLLATO (1997) drying beans (Phaseolus vulgaris L.) through natural way, in effective 11 hours of drying in the sun, excluding the night and the rest period of 15.5 hours, reported that the moisture content increased from $25.4 \%$ to $13.1 \%$. BRAGA et al. (2005) built a dryer with solar heat in a barge type, and they used it in the dehydration of beans (Phaseolus vulgaris L.), thus reducing the drying time by $83 \%$ compared with the traditional system (drying in the yard).

SANTOS (2004), studying a methodology for dimensioning solar heating systems for drying agricultural products, dried 1.2 tons of corn using a specific air volumetric flow rate equal to $1,20 \mathrm{~m}^{3} \mathrm{~min}^{-1} \mathrm{~m}^{-2}$, at a temperature of $50{ }^{\circ} \mathrm{C}$, obtaining a $31 \%$ saving in energy demand for heating air. MORAES NETO et al. (1998), dehydrated banana (Musa sp.) ripe and green for 18 hours in the sun, combined with oven to produce a low cost meal, obtaining on average $13.8 \%$ for ripe banana and $7.2 \%$ for green bananas.

\section{Drying in solar dryer}

Figure 4 presents the experimental points of drying almonds WP, WWP, HWP and HP, with their respective control (C), using the solar dryer combined with HAND dryer. Curves which originate from linear fitting to the experimental data into three sections are also shown, the first being drying in the daytime dryer, the second being in the HAND dryer and control, and the third in the daytime dryer again.
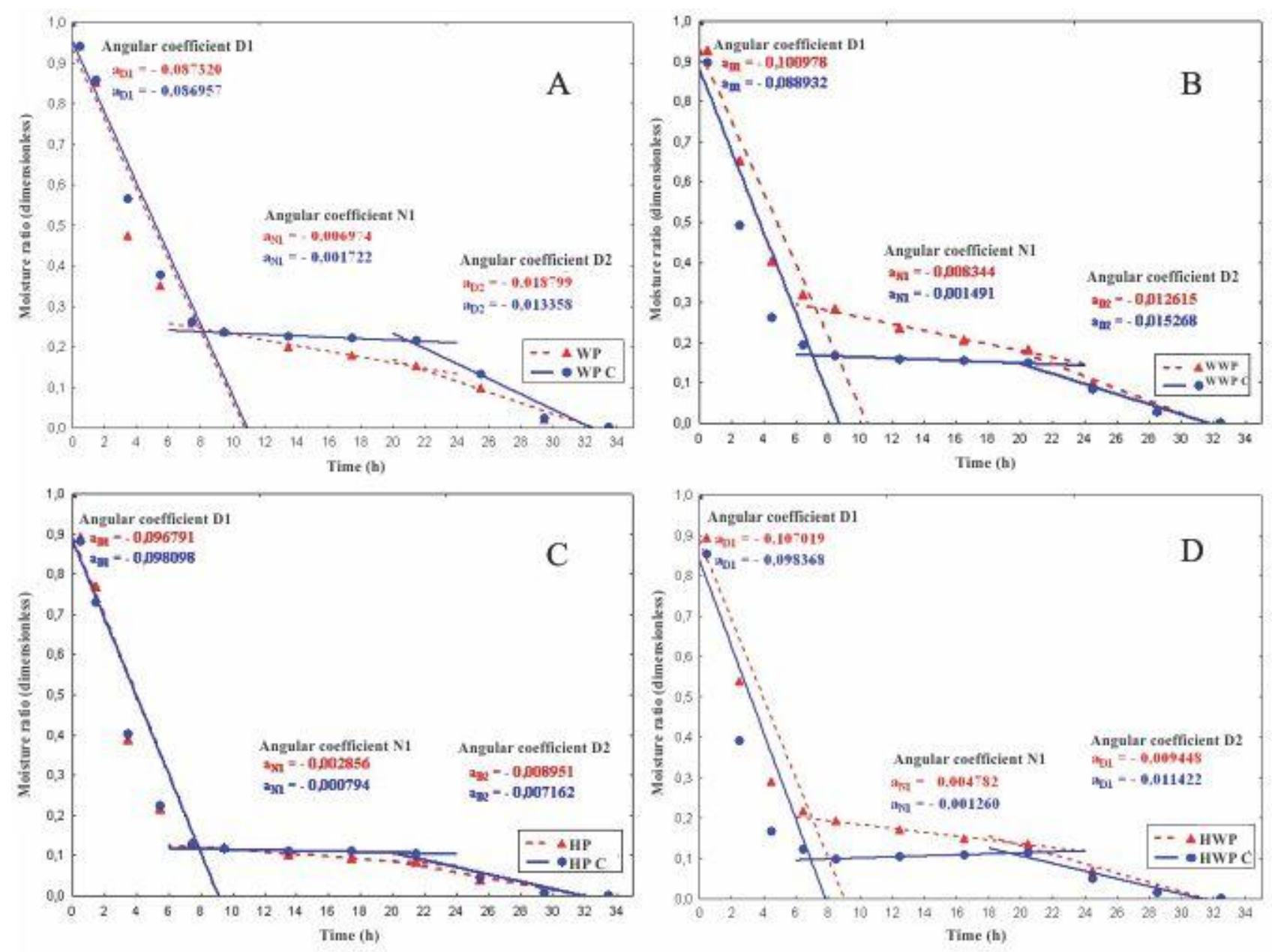

FIGURE 4. Drying curves of almonds WP (A), WWP (B), HP (C) and HWP (D) in solar dryer combined with HAND dryer. 
It is observed within the first 10 hours of drying, spent during the daytime, a fast decrease in the samples ratio of water and a similar pattern for the four sample types (WP, WWP, HWP and HP). The drying in the period (first eight hours of drying) led, in most cases, to reductions in the ratio of water to values below 0.3 ; in the period of 10 until 22 hours, when drying takes place at night, it was noted faster reductions in water samples placed in the HAND dryer compared to the control, considering that in the WWP sample this difference is most striking, with the angular coefficient of the drying curve in the HAND dryer 5.6 times greater than the coefficient of the control curve; in addition, at night the control samples reached moisture gain; from the 22 hours of drying and so on, when the daylight drying began again, initial moisture changed by $51 \%$ to $49 \%$ in samples WP, WWP, HWP and HP.

MWITHIGA \& OLWAL (2005), in a dryer using solar energy for drying coffee, managed to reduce the moisture of the grain of $54.8 \%$ to moisture less than $13 \%$ in two days, instead of five to seven days used in drying direct in sunlight. In this study, the use of daytime dryers and the overnight use provided a drying in which all samples had minimum final moisture ratio with values below 13\% in about 36 hours of drying. Drying of the HP samples with daytime dryers and overnight use resulted in moisture of $13 \%$ at the end of 22 hours.

EL-BELTAGY et al. (2007), using a solar dryer of indirect heating, which reached a maximum air temperature of drying of $46.8^{\circ} \mathrm{C}$, dehydrated strawberries in halves, whole, in quarters and in slices, in 28; 26; 24 and 20 hours of drying; under these conditions, the authors have produced samples with final moisture content of $18.5 \%$ for whole strawberries, $13.1 \%$ for halves, $11.5 \%$ for quarters, and $11.3 \%$ for those cut in slices. CAMPOS et al. (2004) built a wood-fired dryer, with fixed layers, for grains, using it in the dehydration of coffee at a temperature of $43{ }^{\circ} \mathrm{C}$ and air flow of $21 \mathrm{~m}^{3} \mathrm{~min}^{-1} \mathrm{~m}^{-2}$, reducing the moisture content of the product of $43.1 \%$ to $12.7 \%$, in 42 hours.

\section{Comparison of solar dryer with oven of almonds jackfruit}

Table 1 lists the fitting parameters for the logarithmic model to the data of the kinetics drying of almonds WP, WWP, HWP and HP, the respective determination coefficients $\left(\mathrm{R}^{2}\right)$ and the meansquare deviation (MSD). It can be seen that the logarithmic model had values of determination coefficients $\left(\mathrm{R}^{2}\right)$ greater than 0.99 and of MSD less than $1 \%$ for all samples, at temperatures of $40{ }^{\circ} \mathrm{C}, 50{ }^{\circ} \mathrm{C}$ and $70{ }^{\circ} \mathrm{C}$. Several authors have also achieved excellent adjustments with the logarithmic model, as TOGRUL \& PEHLIVAN (2003) with apricot, DOYMAZ $(2004 ; 2007)$ with cranberry and pumpkin, GOYAL et al. (2007) with plum, SACILIK (2007) with pumpkin seed, XANTHOPOULOS et al. (2007) with fig, and WANG et al. (2007) with apple.

Table 2 shows the fitting parameters for the logarithmic model to the data of the kinetics drying of almonds WP, WWP, HWP and HP and the respective determination coefficients $\left(\mathrm{R}^{2}\right)$ and the mean-square deviation (MSD), for both methods of drying: drying by direct exposure to the sun (DES) and drying in solar dryer (DSD), both combined with HAND dryer. It is observed that, for both drying, the logarithmic model fitted well to the experimental data, with $\mathrm{R}^{2}>0.98$ and $\mathrm{MSD}<1 \%$. 
TABLE 1. Parameters of the logarithmic model, with respective determination coefficients $\left(\mathrm{R}^{2}\right)$ and mean-square deviation (MSD) of the kinetics drying of jackfruit almonds.

\begin{tabular}{|c|c|c|c|c|c|c|}
\hline \multirow{2}{*}{ Sample } & \multirow{2}{*}{ Temperature $\left({ }^{\circ} \mathrm{C}\right)$} & \multicolumn{3}{|c|}{ Parameter } & \multirow{2}{*}{$\mathrm{R}^{2}$} & \multirow{2}{*}{ MSD } \\
\hline & & $\mathrm{A}$ & $\mathrm{K}$ & $\mathrm{C}$ & & \\
\hline \multirow{5}{*}{ WP } & 40 & 1.0289 & 0.0444 & -0.0519 & 0.9991 & 0.0563 \\
\hline & 50 & 1.0089 & 0.0961 & -0.0166 & 0.9996 & 0.0406 \\
\hline & 60 & 0.9966 & 0.1835 & 0.0044 & 0.9998 & 0.0241 \\
\hline & 70 & 0.9835 & 0.2686 & 0.0170 & 0.9996 & 0.0343 \\
\hline & 80 & 0.9426 & 0.3688 & 0.0317 & 0.9985 & 0.0728 \\
\hline \multirow{7}{*}{ WWP } & \multirow{2}{*}{ Temperature $\left({ }^{\circ} \mathrm{C}\right)$} & & arameter & & \multirow{2}{*}{$\mathrm{R}^{2}$} & \multirow{2}{*}{ MSD } \\
\hline & & $\mathrm{A}$ & $\mathrm{K}$ & $\mathrm{C}$ & & \\
\hline & 40 & 0.9220 & 0.2329 & 0.0445 & 0.9957 & 0.0918 \\
\hline & 50 & 0.9314 & 0.2579 & 0.0382 & 0.9975 & 0.0932 \\
\hline & 60 & 0.9505 & 0.3284 & 0.0275 & 0.9984 & 0.0731 \\
\hline & 70 & 0.9419 & 0.3805 & 0.0245 & 0.9984 & 0.0692 \\
\hline & 80 & 0.9304 & 0.5006 & 0.0323 & 0.9975 & 0.0846 \\
\hline \multirow{7}{*}{$\mathrm{HP}$} & \multirow{2}{*}{ Temperature $\left({ }^{\circ} \mathrm{C}\right)$} & & arameter & & \multirow{2}{*}{$\mathrm{R}^{2}$} & \multirow{2}{*}{ MSD } \\
\hline & & A & $\mathrm{K}$ & $\mathrm{C}$ & & \\
\hline & 40 & 0.9547 & 0.1377 & 0.0072 & 0.9991 & 0.0407 \\
\hline & 50 & 0.9319 & 0.2476 & 0.0204 & 0.9988 & 0.0589 \\
\hline & 60 & 0.9520 & 0.3434 & 0.0218 & 0.9991 & 0.0549 \\
\hline & 70 & 0.9425 & 0.4764 & 0.0207 & 0.9988 & 0.0602 \\
\hline & 80 & 0.9139 & 0.6101 & 0.0374 & 0.9957 & 0.1056 \\
\hline \multirow{7}{*}{ HWP } & \multirow{2}{*}{ Temperature $\left({ }^{\circ} \mathrm{C}\right)$} & & arameter & & \multirow{2}{*}{$\mathrm{R}^{2}$} & \multirow{2}{*}{ MSD } \\
\hline & & $\mathrm{A}$ & $\mathrm{K}$ & $\mathrm{C}$ & & \\
\hline & 40 & 0.9266 & 0.3098 & 0.0388 & 0.9964 & 0.0861 \\
\hline & 50 & 0.9189 & 0.3943 & 0.0371 & 0.9966 & 0.1061 \\
\hline & 60 & 0.9392 & 0.4748 & 0.0315 & 0.9974 & 0.0906 \\
\hline & 70 & 0.9280 & 0.5397 & 0.0299 & 0.9971 & 0.0924 \\
\hline & 80 & 0.9214 & 0.6740 & 0.0358 & 0.9956 & 0.1051 \\
\hline
\end{tabular}

TABLE 2. Parameters of the logarithmic model with respective determination coefficients $\left(\mathrm{R}^{2}\right)$ and mean-square deviation (MSD) of kinetics drying by direct exposure to the sun and solar dryer.

\begin{tabular}{|c|c|c|c|c|c|c|}
\hline \multirow{2}{*}{ Treatment } & \multirow{2}{*}{ Drying method } & \multicolumn{3}{|c|}{ Parameter } & \multirow{2}{*}{$\mathrm{R}^{2}$} & \multirow{2}{*}{ MSD } \\
\hline & & $\mathrm{a}$ & K & $\mathrm{C}$ & & \\
\hline \multirow{2}{*}{ WP } & DES & 5.5124 & 0.0052 & -4.5735 & 0.9908 & 0.1002 \\
\hline & DSD & 0.9412 & 0.2081 & 0.0853 & 0.9873 & 0.1664 \\
\hline \multirow{2}{*}{ WWP } & DES & 1.0752 & 0.0675 & -0.0979 & 0.9972 & 0.0524 \\
\hline & DSD & 0.9257 & 0.2903 & 0.0723 & 0.9924 & 0.1658 \\
\hline \multirow{2}{*}{$\mathrm{HP}$} & DES & 1.4999 & 0.0289 & -0.5436 & 0.9917 & 0.1059 \\
\hline & DSD & 0.9861 & 0.2817 & 0.0420 & 0.9940 & 0.1154 \\
\hline \multirow{2}{*}{ HWP } & DES & 1.0663 & 0.0764 & -0.0785 & 0.9981 & 0.0493 \\
\hline & DSD & 0.9408 & 0.4027 & 0.0578 & 0.9956 & 0.1394 \\
\hline
\end{tabular}

Figure 5 shows the drying curves of jackfruit almonds, adjusted by the logarithmic model, for the samples WP, WWP, HWP and HP, dried by exposure to direct sunlight combined with HAND dryer and oven, at temperatures of $40{ }^{\circ} \mathrm{C}$ and $50{ }^{\circ} \mathrm{C}$. 
The choice of drying temperatures in oven aimed at confronting the solar dryer and the oven that had comparable performance, i.e., approximate drying times.
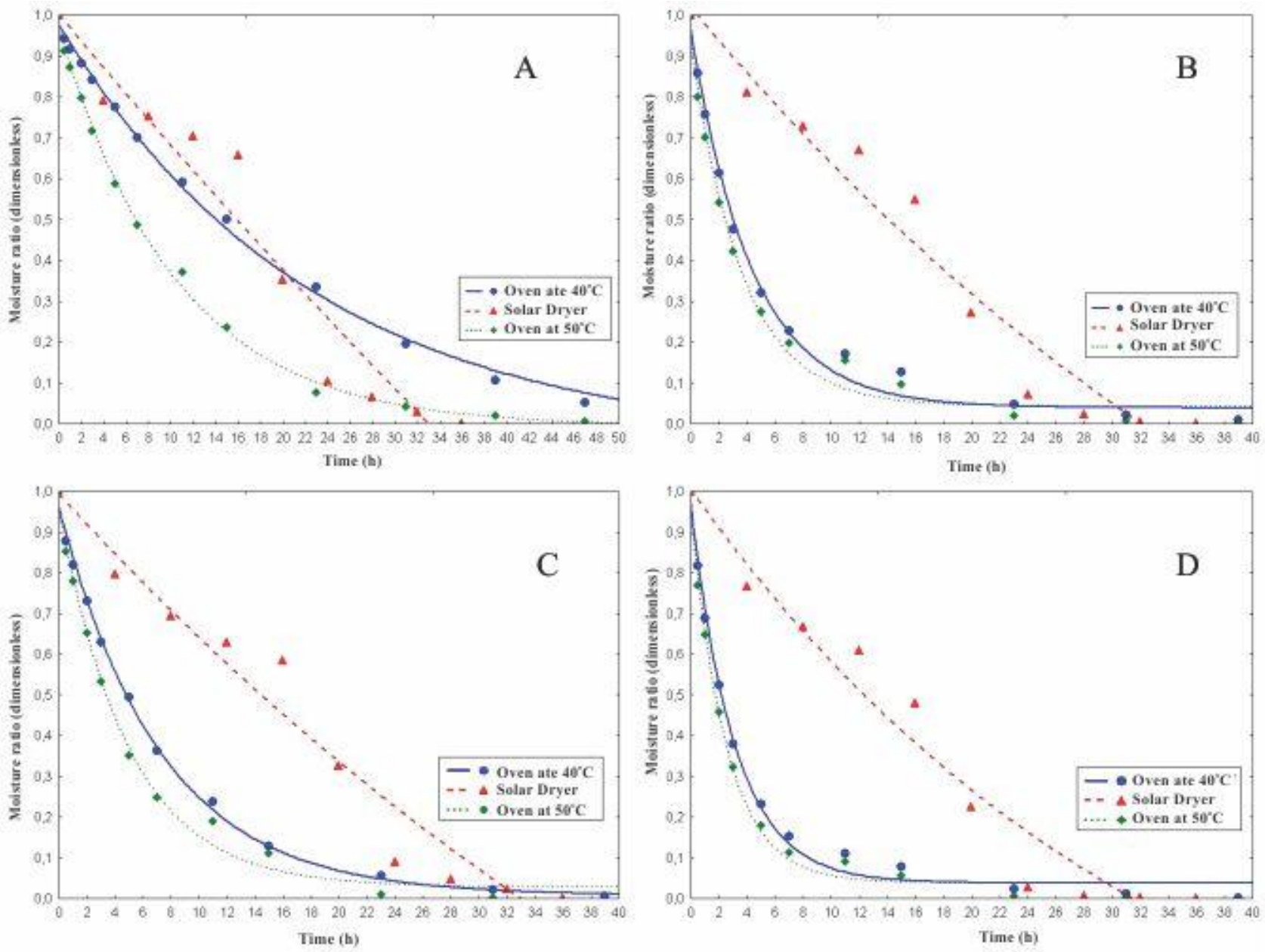

FIGURE 5. Comparison of drying of jackfruit almonds WP (A), WWP (B), HP (C) and HWP (D) by direct exposure to sun combined with HAND dryer and the oven at $40{ }^{\circ} \mathrm{C}$ and $50{ }^{\circ} \mathrm{C}$.

In the solar drying, the overnight period goes from 0 hour to 12 hours (beginning of the drying) and from 24 hours to 36, on the last day, while daytime drying goes from 12 hours to 24; it can be observed, in the four figures, the best performance of drying in an oven during the first hours of testing, corresponding to the overnight period; over 15 hours, with the samples in solar dryer, the samples of water ratio is comparable to the samples in an oven, and remained in that way until the end of drying, even after the beginning of a new period of overnight drying. In spite of the equivalence with artificial drying at relatively low temperatures, it can be considered that it was obtained a good time for drying with solar energy, according to other studies, such as SCHIRMER et al. (1996) who also made comparison of drying methods, investigating the banana drying in tunnel type solar dryer and direct sunlight. According to the authors, the process took three to five days in a tunnel and 5 to 7 in direct exposure. MORAES NETO et al. (1998), evaluating the drying of green and ripe bananas in direct sunlight, could reduce the water content of the samples to an average of $10.5 \%$, after four days of intermittent drying, the same time was reported by BERTORELLI et al. (2004) when drying cocoa in the direct sunlight with the samples placed on cement base.

Figure 6 shows the drying curves, adjusted by the logarithmic model, for the samples WP, WWP, HWP and HP, dried in solar dryer combined with the HAND dryer and oven, at temperatures of $40^{\circ} \mathrm{C}$ to $70^{\circ} \mathrm{C}$, temperatures which were chosen for presenting the approximate 
drying time of drying using solar energy. It is observed that solar drying is comparable to the artificial drying during daytime and that the use of the HAND dryer prevented the absorption of water by the samples during the night.
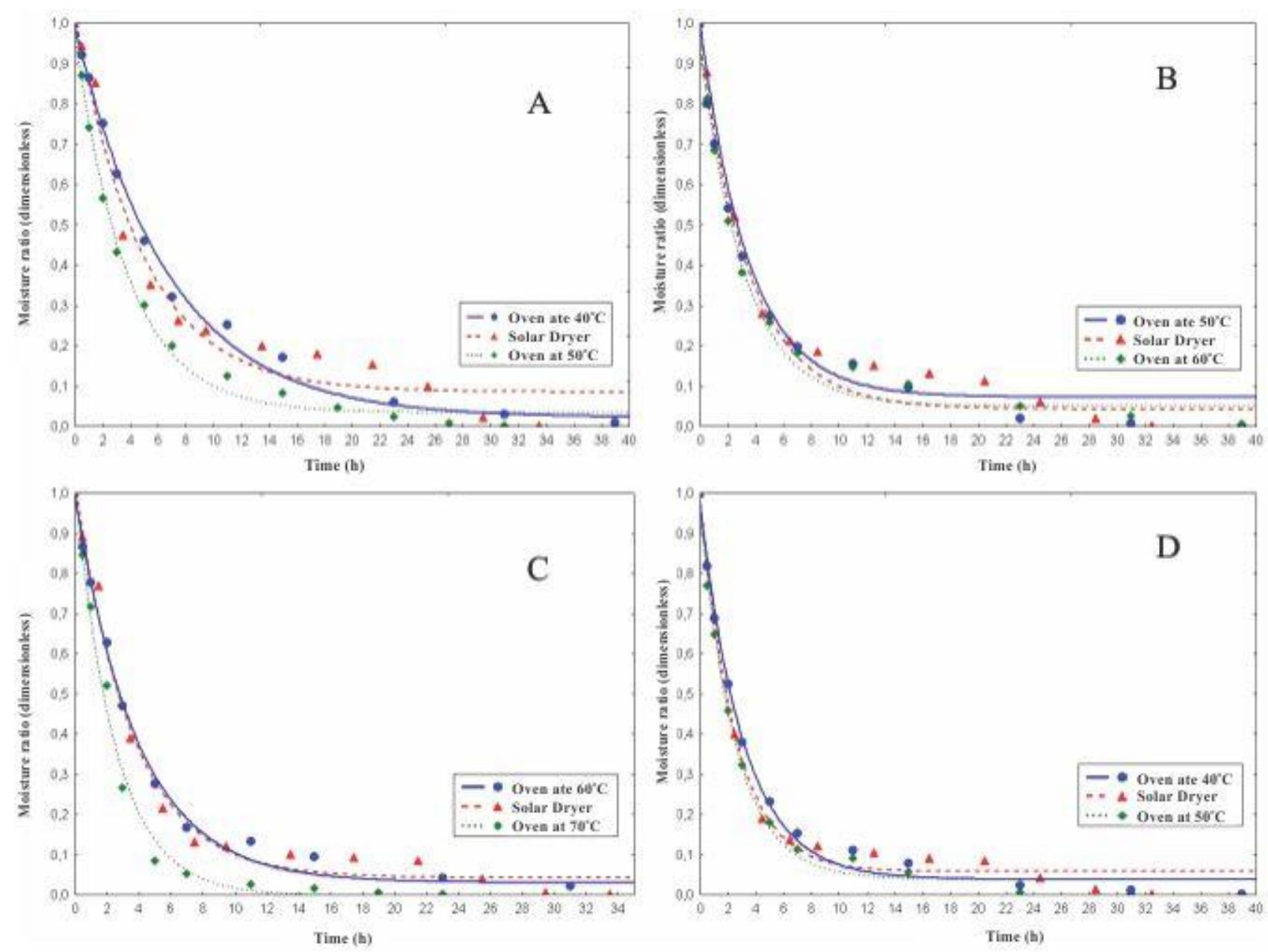

FIGURE 6. Comparison of drying of jackfruit almonds WP (A), WWP (B), HP (C) and HWP (D) in solar dryer combined with HAND dryer and the oven at $40^{\circ} \mathrm{C}$ and $70^{\circ} \mathrm{C}$.

\section{CONCLUSIONS}

The accumulation of heat generated by solar energy in a volume of water used in the HAND dryer technically makes viable to be used for drying jackfruit almonds overnight.

The drying combining the use of dryers based on solar energy equivalents to drying in an oven at temperatures between $40{ }^{\circ} \mathrm{C}$ and $70{ }^{\circ} \mathrm{C}$. drying.

The removal of the pellicle and the almonds cut in half of jackfruit almonds promoted faster

\section{REFERENCES}

AHRENS, D.C.; LOLLATO, M.A. Secagens ao sol e artificial de sementes de feijão: curvas de secagem e efeitos sobre a qualidade fisiológica. Revista Brasileira de Sementes, Brasília, v.19, n.1, p.22-27, 1997.

BERTORELLI, L.O.; CAMACHO, G.; FARIÑAS, L.G. Efecto del secado al sol sobre la calidad del grano fermentado de cacao. Agronomía Tropical, Maracay, v.54, n.1, p.1-11, 2004. 
BRAGA, C. A. da. S.; MOREIRA, C.A.; PECHE FILHO, A.; BERNARDI, J.A.; MELLO, R. da. C.; STORINO, M.; LINO, A.C.L. Desenvolvimento e avaliação de um secador solar para grãos, associado a silo subterrâneo. Revista Brasileira de Engenharia Agrícola e Ambiental, Campina Grande, v.9, n.4, p.666-670, 2005.

CAMPOS, A.T.; MELO, E.C.; SILVA, J.S. Análise energética de secador de grãos a lenha. In: CONGRESSO INTERNACIONAL SOBRE GERAÇÃO DISTRIBUÍDA E ENERGIA NO MEIO RURAL, 5., 2004, Campinas. Anais... Campinas: NIPE/SBEA/UNICAMP, 2004. 1 CD - ROM.

DOYMAZ, I. Drying kinetics of white mulberry. Journal of Food Engineering, Oxford, v.61, n.3, p.341-346, 2004.

DOYMAZ, I. The kinetics of forced convective air-drying of pumpkin slices. Journal of Food Engineering, Oxford, v.79, n.1, p.243-248, 2007.

EL-BELTAGY, A.; GAMEA, G.R.; ESSA, A.H.A. Solar drying characteristics of strawberry. Journal of Food Engineering, Oxford, v.78, n.2, p.456-464, 2007.

GIRALDO-ZUNIIGA, A.D.; PINEDO, A.A.; RODRIGUES, R.M. The air drying behavior of osmotically dehydrated for jackfruit (Artocarpus integrifólia) slices. In: INTERNATIONAL DRYING SYMPOSIUM, 14., 2004, São Paulo. Proceedings... São Paulo: UNICAMP, 2004. 1 CD - ROM.

GOYAL, R.K.; KINGSLY, A.R.P.; MANIKANTAN, M.R.; ILYAS, S.M. Mathematical modelling of thin layer drying kinetics of plum in a tunnel dryer. Journal of Food Engineering, Oxford, v.79, n.1, p.176-180, 2007.

MARTINS, R.R.; FRANCO, J.B.R.; OLIVEIRA, P.A.V.; GOMES, J.R.S.; FRANSOZI, C.D P. Secador de grãos com energia solar. Agroecologia e Desenvolvimento Rural Sustentável, Porto Alegre, v.3, n.1, p.29-35, 2002.

MORAES NETO, J.M.; CIRNE, L.E.M.R.; PEDROZA, J.P.; SILVA, M.G. Componentes químicos da farinha de banana (Musa sp.) obtida por meio de secagem natural. Revista Brasileira de Engenharia Agrícola e Ambiental, Campina Grande, v.2, n.3, p.316-318, 1998.

MWITHIGA, G.; OLWAL, J.O. The drying kinetics of kale (Brassica oleracea) in a convective hot air dryer. Journal of Food Engineering, Oxford, v.71, n.4, p.373-378, 2005.

SACILIK, K. Effect of drying methods on thin-layer drying characteristics of hull-less seed pumpkin (Cucurbita pepo L.). Journal of Food Engineering, Oxford, v.79, n.1, p.23-30, 2007.

SANTOS, B.M. Metodologia de dimensionamento de sistemas de aquecimento solar para secagem de produtos agrícolas. 2004. 66 f. Dissertação (Mestrado em Engenharia Agrícola) - Universidade Estadual de Campinas, Campinas, 2004.

SCHIRMER, P.; JANJAI, S.; ESPER, A.; SMITABHINDU, R.; MÜHLBAUER, W. Experimental investigation of the performance of the solar tunnel dryer for drying bananas. Renewable Energy, Oxford, v.7, n.2, p.119-129, 1996.

TOGRUL, I.T.; PEHLIVAN, D. Modelling of drying kinetics of single apricot. Journal of Food Engineering, Oxford, v.58, n.1, p.23-32, 2003.

TULYATHAN, V.; TANANUWONG, K.; SONGJINDA, P.; JAIBOON, N. Some physicochemical properties of jackfruit (Artocarpus heterophyllus Lam) seed flour and starch. Science Asia, Tailândia, v.28, n.1, p.37-41, 2002.

WANG, Z.; SUN, J.; LIAO, X.; CHEN, F.; ZHAO, G.; WU, J.; HU, X. Mathematical modeling on hot air drying of thin layer apple pomace. Food Research International, Barking, v.40, n.1, p.39-46, 2007. 
XANTHOPOULOS, G.; OIKONOMOU, N.; LAMBRINOS, G. Applicability of a single-layer drying model to predict the drying rate of whole figs. Journal of Food Engineering, Oxford, v.81, n.3, p.553-559, 2007. 